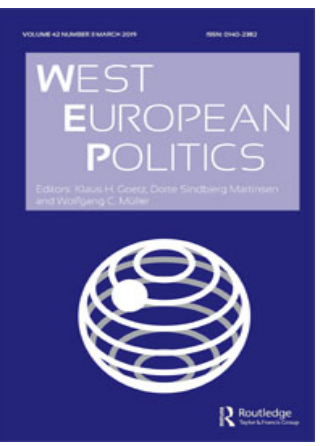

West European Politics

\title{
The Italian election of 2018 and the first populist government of Western Europe
}

\section{Diego Garzia}

To cite this article: Diego Garzia (2019) The Italian election of 2018 and the first populist government of Western Europe, West European Politics, 42:3, 670-680, DOI: 10.1080/01402382.2018.1535381

To link to this article: https://doi.org/10.1080/01402382.2018.1535381

曲 Published online: 06 Dec 2018.

Submit your article to this journal $\pi$

Џlll Article views: 344

View Crossmark data $₫$ 


\section{The Italian election of 2018 and the first populist government of Western Europe}

Diego Garzia

Department of Political Science, Universität, Luzern, Switzerland

\section{Background to the election}

The 2013 election had heralded an unprecedented tripolar era for Italian politics, with the two traditional forces of the Second Italian Republic (Silvio Berlusconi's centre-right and variously assorted centre-left alliances) eventually matched, in terms of size, by the Movimento 5 Stelle (M5S) - to date, the most successful rookie of Italian politics with $25 \%$ of valid votes at its first national election (Garzia 2013). Such an impressive result, although insufficient to grant it the majority bonus in the Lower Chamber, had nonetheless been enough to complicate, to a large extent, the formation of a parliamentary majority. Indeed, the problematic nature of the electoral outcome resulted in a correspondingly long process of government formation, which took over two months. On 28 April 2013, the President of the Republic, Giorgio Napolitano, appointed Enrico Letta as the head of a unity government featuring personnel from both Partito Democratico (PD) and Popolo delle Libertà (PdL). This parliamentary majority, however, only lasted until November 2013, when Silvio Berlusconi led the PdL's withdrawal from the government and the simultaneous reversion of the name of his party to its original denomination Forza Italia (FI). This event led in turn to the formation of a smaller fringe party - Nuovo Centro Destra (NCD) - which, under the leadership of Angelino Alfano, decided not to withdraw from government.

In a matter of just a few weeks, the process of political change took another turn with the 'primary' elections for the leaderships of both the PD and the Lega Nord (LN). On 8 December, Matteo Renzi became the new leader of the PD, while Matteo Salvini became leader of the LN. Persistent tensions followed Renzi's election as Secretary of the PD, and eventually culminated in Letta's resignation as Prime Minister in February 2014. Renzi quickly took over as a result and formed a new government 
based on the same coalition of parties supporting Letta's cabinet (PD and NCD). A strong mandate from his party and high government popularity figures allowed Renzi to lead PD to a strong showing in the 2014 European Parliament election (Segatti et al. 2015).

However, this deferred honeymoon came to an end with the constitutional referendum proposed by Renzi's government. Eventually, the constitutional reform was rejected on 4 December 2016 with 59 percent of votes against it. Following defeat, and as a result of his strong personalisation strategy (Ceccarini and Bordignon 2017), Renzi stepped down as Prime Minister and was replaced by his Minister of Foreign Affairs and co-founder of the PD, Paolo Gentiloni. Under Gentiloni's leadership, the government carried the country to general elections at the natural end of the legislative term, yet under totally different (proportional) rules, as will be seen below. On 29 December 2017, President Sergio Mattarella dissolved parliament and a new general election was called for 4 March 2018.

\section{Coalitions, leaders and a new electoral system}

As a consequence of the 2016 constitutional referendum - which was itself tied to a previously attempted electoral reform under the name of Italicum - and of two different sentences of the Constitutional Court, the electoral laws for the two houses of the Italian Parliament lacked uniformity. The new electoral system known as Rosatellum (from the name of its proponent, Ettore Rosato, head of PD's faction in the Lower Chamber) was approved in October 2017, with the parliamentary support of PD, FI, LN and minor parties. It is a mixed system, with $37 \%$ of seats in each Chamber allocated through first-past-the-post (FPTP) in singlemember constituencies, and $63 \%$ by national proportional representation in multi-member constituencies. The law recognises the existence of preelectoral coalitions, and therefore the thresholds - equal for both chambers - are differentiated for party lists (3\%) and coalitions (10\%). Interestingly, those lists below 3\% (but above 1\%) that are not entitled to gain representation in parliament are nonetheless able to bring their votes to the respective coalition - provided the coalition itself is able to overcome the $10 \%$ threshold. Voters are allowed to cast their two votes (one for the FPTP, another for the proportional part) on a single ballot paper featuring both the names of the candidates to single-member constituencies and, in close conjunction with them, the symbols of the linked lists for the proportional part, each one with a list of the related candidates. The panachage is not allowed, under penalty of invalidation - so the voter cannot vote simultaneously for a candidate in the FPTP constituency and for a list which is not linked to them. This feature is paradigmatic of this 
electoral system, as it homogenises by default the voters' choice around candidates and parties from the same party/coalition, irrespective of the potential appeal of FPTP candidates - thus de-potentiating the essence of a mixed system.

The 2018 election was contested by three main factions (centre-left, centre-right, and M5S) plus a minor left-wing contender. The centre-left coalition contested the election under Matteo Renzi's renewed leadership after his re-election as party secretary in the primary elections of April 2017 - despite his declared intention to leave politics once and for all, had the 2016 constitutional referendum been rejected. According to the PD's statute, the party secretary is in fact also the party's candidate for Prime Minister. Nevertheless, the ambiguity that surrounded the coalition leadership throughout the whole campaign must be noted, with incumbent Prime Minister Gentiloni hardly in the spotlight but never openly excluded for the possibility to lead the coalition in the aftermath of the election. Indeed, the PD did not face the election on its own. Junior partners of the centre-left coalition consisted of + Europa, led by long-time Radical Party leader Emma Bonino; Insieme, an electoral alliance formed by the Italian Socialist Party, the Federation of the Greens, and some assorted vintage personnel dating back to Romano Prodi's Ulivo experience; Civica Popolare, led by incumbent Minister of Health Beatrice Lorenzin and which included all those members of Alfano's NCD who decided to remain loyal to the centre-left coalition. The centre-left coalition also included its traditional French-speaking (VdA) and German-speaking (SVP) allies. A left-wing fringe contested the election in opposition to the centre-left coalition under the denomination Liberi $e$ Uguali (LeU). In early 2017, a number of PD founding members including Massimo D'Alema and former party leader Pierluigi Bersani abandoned the party in opposition to Renzi's policies and supported the formation of LeU under the leadership of Pietro Grasso, President of the Senate and former anti-mafia prosecutor.

The main stakeholders of the centre-right coalition were Berlusconi's FI and Salvini's LN. The declining popularity of Berlusconi and the rapid rise of Salvini's LN led to an unprecedented agreement: the leader of the coalition would have corresponded to the leader of the party gaining more votes at the following election. Similar to Renzi, also Salvini was reelected federal secretary of his party in spring 2017. Under his leadership, the party quickly moved towards an 'Italian nationalist' populist force, destroying any notion of northern separatism and emphasising in primis Euroscepticism and anti-immigration attitudes (Albertazzi et al. 2018). Suffice it to say that the new Lega does not even feature the word 'North' in the party symbol anymore. Smaller coalition partners for the centre- 
right included the extreme-right Fratelli d'Italia (FdI) led by Giorgia Meloni, and Noi con l'Italia (NcI) the splinter of NCD that decided to leave the government camp.

With regard to the M5S, its first parliamentary term highlighted a continued support among the public (21\% in the EP election of 2014 and a growing number of municipalities under its control, including Rome and Turin) in spite of the drastic changes in the party structure and leadership positions. Party founder and chief strategist Gianroberto Casaleggio died on 12 April 2016, to be replaced by his son Davide. In September 2017 another fundamental change took place, with the selection of Luigi Di Maio - by then vice-president of the Chamber of Deputies - as the movement's candidate for Prime Minister and 'political head', thus replacing Beppe Grillo.

\section{The campaign}

Already in December 2017, the foreseeable outcomes of the complex electoral law were at the core of the public discourse. The move from a largely bipolar context towards a tripolar one was further complicated by a proportional setting in which the declining electoral strength of the traditional centre-left and centre-right coalitions was coupled with the explicit unwillingness of the M5S to make compromises with any of them after the election. Against this background, virtually all journalists and commentators supported the idea that the electoral outcome would not result in a functioning parliamentary majority (Mancini and Roncarolo 2018). This feeling of indecisiveness accompanied the whole campaign and marked its rather low level of engagement with leaders and issues. As with the previous elections, no leaders' debate took place on television this time also as a result of the ambiguities regarding the actual leadership for both the centre-left and the centre-right coalitions. Silvio Berlusconi dusted off one of his most celebrated campaign work-horses by signing a new 'Contract with the Italians' in Bruno Vespa's late night show for the national television channel. In a similar vein, Matteo Salvini committed, again in front of the cameras, to the immediate abolition of all excise duty on petrol - yet to be seen.

Overall, party manifestos remained vague and largely unrealistic as well (for a better discussion, see Amato and Perotti 2018). The defining pledges for the main leaders' campaign can be summarised as follows: Silvio Berlusconi insisted on tax reduction, this time in the form of a 'flat tax'; Matteo Salvini backed up Berlusconi's proposal without any hesitation, but focused his campaign on anti-immigration and security stances; Matteo Renzi backed Gentiloni's policies and promised to enlarge the pool of recipients for the ' 80 Euros', a tax deduction approved during his 
political tenure - this time in the form of a monthly allowance for parents of each minor child; finally, Luigi Di Maio forcefully grounded the whole M5S campaign around its trademark proposal known as 'income of citizenship' (consisting of $€ 780$ monthly to the large pool of unemployed Italian voters).

The overall un-persuasiveness of the 2018 campaign can be assessed against the (lack of) party conversion rate over the campaign itself, as shown in Figure 1, as well as the relatively stable degrees of (un)popularity for the main party leaders, as illustrated in Figure 2.

Against this background, one could interpret the overall campaign as an attempt by the major leaders and coalitions to (re)appeal to their traditional constituencies. This 'static' interpretation, however, must be complemented with the observation that public opinion concerns have changed throughout the legislature. A fairer picture would thus need to take into account longer-term processes in public opinion that can potentially account for the decline of traditional government forces (PD and FI) at the expense of oppositions (LN) and outsiders (M5S). Eurobarometer data shows that in 2013 the major concerns of Italian voters were unemployment (58\%) and economic growth (42\%), with immigration only mentioned as an important problem faced by the country by $4 \%$ of respondents. The picture in 2017 is rather different, with traditional concerns regarding the state of the economy diminished at the expense of immigration (now mentioned as an important problem by $33 \%$ of the sample). While this is a key to understanding Salvini's long-term strategy, it must be coupled with the observation that the issue of unemployment diminished by 16 percentage points and yet it remained overall the most important factor for Italian voters. In all likelihood, this played in favour of M5S' strategy to emphasise the citizenship income as its flagship proposal.

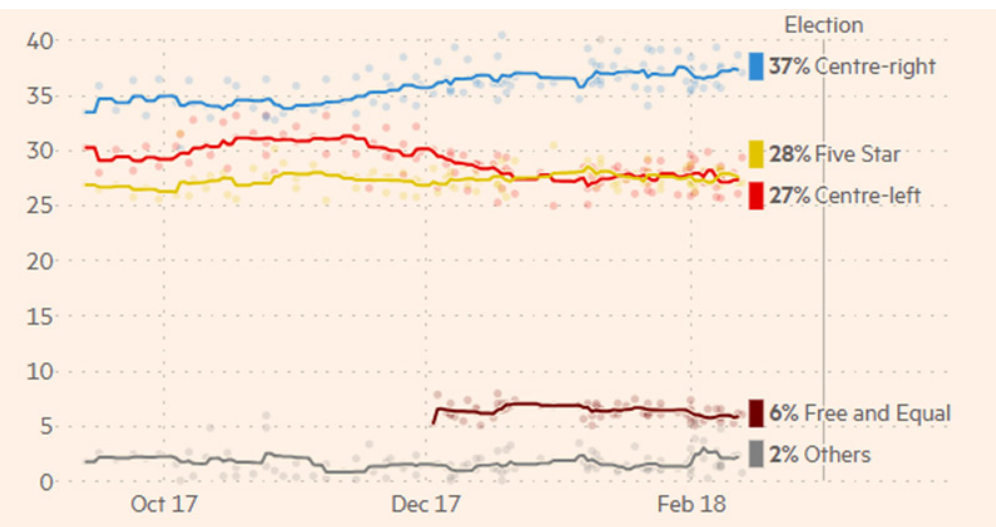

Figure 1. Voting intentions for coalitions (October 2017 to February 2018). Source: https://ig.ft.com/italy-poll-tracker/ 


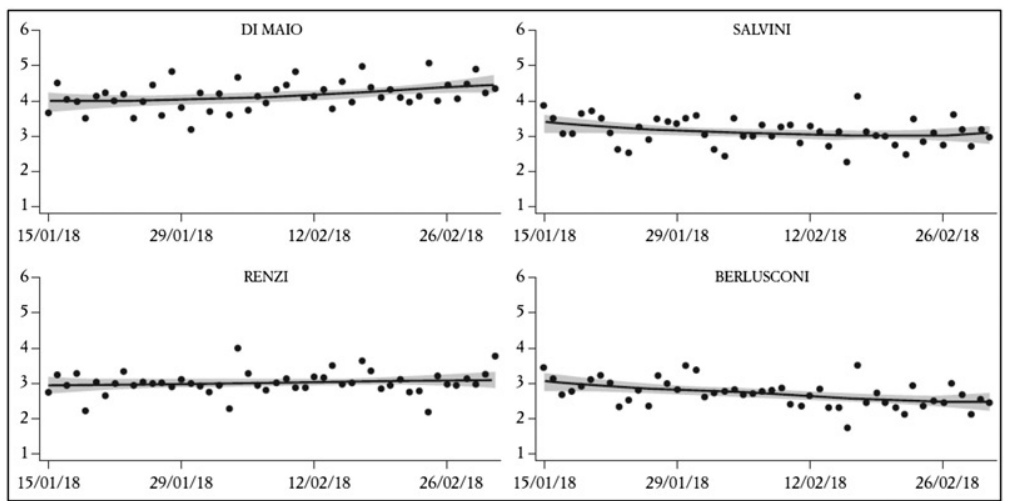

Figure 2. The popularity of main party leaders across the electoral campaign. Source: Garzia and Venturino (2018).

\section{The result}

The election of 4 March 2018 saw the participation of $72.9 \%$ of the eligible voting population (the lowest figure ever in the history of the Italian Republic, $-2.3 \%$ as compared to the by then all-time low of 2013). According to Table 1, the coalition that received most votes was the centre-right (37\%, fully in line with pre-electoral expectations based on opinion polls). Within the coalition, it is noteworthy that there was a massive gain by Salvini's LN $(+13 \%$ as compared to 2013 , the most voted-for party in the coalition) as well as the decline of Berlusconi's FI ( $-7 \%$ as compared to 2013, enough to lose for the first time since 1994 the numeric supremacy in the coalition). Amongst the winners, Di Maio's M5S must certainly be mentioned, with a further increase of $7 \%$ vis-à-vis 2013 and now the largest political force in the country commanding virtually one out of three votes (33\%, four points higher than pre-electoral polls). When it comes to the losers of the 2018 election, one cannot avoid pointing at $\mathrm{PD}$, falling below $20 \%(-7 \%$ as compared to 2013 and the worst result ever in its history). If numerically this was enough for it to score as the second biggest party in the country, the poor performance of its coalition partners has resulted in the centre-left becoming the third political force in the country.

In order to account for such continuing inter-election volatility, a number of factors must be called into question. A preliminary interpretation could fruitfully address the changing importance of voting determinants across time. First of all, the parties themselves. In this respect, the 2018 election marked the arrival of a long-term trend towards increasing distrust of traditional party actors. As illustrated in Table 2, the 
Table 1. Chamber of Deputies' election results, 2013 and 2018.

\begin{tabular}{|c|c|c|c|c|c|c|}
\hline & \multicolumn{3}{|c|}{2018} & \multicolumn{3}{|c|}{2013} \\
\hline & $\begin{array}{c}\text { Seats } \\
N\end{array}$ & $\begin{array}{l}\text { Votes } \\
\text { (000s) }\end{array}$ & $\begin{array}{c}\text { Votes } \\
\%\end{array}$ & $\begin{array}{c}\text { Seats } \\
N\end{array}$ & $\begin{array}{l}\text { Votes } \\
\text { (000s) }\end{array}$ & $\begin{array}{c}\text { Votes } \\
\%\end{array}$ \\
\hline Movimento 5 Stelle (M5S) & 225 & 10,732 & 32.68 & 109 & 8,689 & 25.55 \\
\hline Partito Democratico (PD) & 107 & 6,161 & 18.76 & 297 & 8,644 & 25.42 \\
\hline Lega (LN) & 123 & 5,698 & 17.35 & 18 & 1,390 & 4.08 \\
\hline Forza Italia $(\mathrm{FI})^{*}$ & 103 & 4,596 & 14.00 & 98 & 7,332 & 21.56 \\
\hline Fratelli d'Italia (Fdl) & 32 & 1,429 & 4.35 & 9 & 665 & 1.95 \\
\hline Liberi e Uguali (LeU) & 14 & 1,114 & 3.39 & - & - & - \\
\hline +Europa $(+\mathrm{E})$ & 2 & 841 & 2.56 & - & - & - \\
\hline Unione di Centro (UdC) & 4 & 427 & 1.30 & 8 & 608 & 1.78 \\
\hline Insieme (I) & 1 & 190 & 0.58 & - & - & - \\
\hline Civica Popolare (CP) & 2 & 178 & 0.54 & - & - & - \\
\hline Südtiroler Volkspartei (SVP) & 4 & 134 & 0.41 & 5 & 146 & 0.43 \\
\hline Scelta Civica (SC) & - & - & - & 39 & 2,824 & 8.30 \\
\hline Sinistra Ecologia Libertà (SEL) & - & - & - & 37 & 1,089 & 3.20 \\
\hline Rivoluzione Civile (RC) & - & - & - & 0 & 765 & 2.25 \\
\hline Fare per Fermare il Declino (FARE) & - & - & - & 0 & 380 & 1.11 \\
\hline Centro Democratico (CD) & - & - & - & 6 & 167 & 0.49 \\
\hline
\end{tabular}

Note: The 2013 result for Forza Italia is that of Popolo della Libertà (PdL). Source: https://elezionistorico.interno.gov.it/

Table 2. Proportion of Italian voters declaring that they trusted political parties (in \%).

\begin{tabular}{lcccc}
\hline 2001 & 2006 & 2008 & 2013 & 2018 \\
\hline 22 & 27 & 19 & 10 & 5 \\
\hline Note: Values for 2001-2013 are the cumulative percentage of respondents with 'a lot' and 'fair \\
amount' of trust in political parties. The value for 2018 \\
reporting values higher than 6 on a 10-point scale.
\end{tabular}

proportion of Italian voters declaring that they trusted political parties in their country plunged to a historic low in 2018 .

Connected to this growing disaffection towards parties lies the intertwined decline of importance on behalf of the left-right divide in driving voters' choice - also due to the effect of M5S' rhetoric in dealigning voters from the traditional left-right categories. Indeed, the proportion of voters unwilling to place themselves on the left-right scale - below $20 \%$ throughout the Italian National Election Study (ITANES) series - rises above $30 \%$ in 2018 . With parties and traditional ideological categories at their weakest, it is to be expected that short-term factors could have played a correspondingly bigger role. Yet this is only partly the case. With regard to the party leaders, their mobilising potential must be understood against the background of their widespread unpopularity albeit slightly improved in 2018 as compared to their annus horribilis in 2013 (Barisione et al. 2013). 


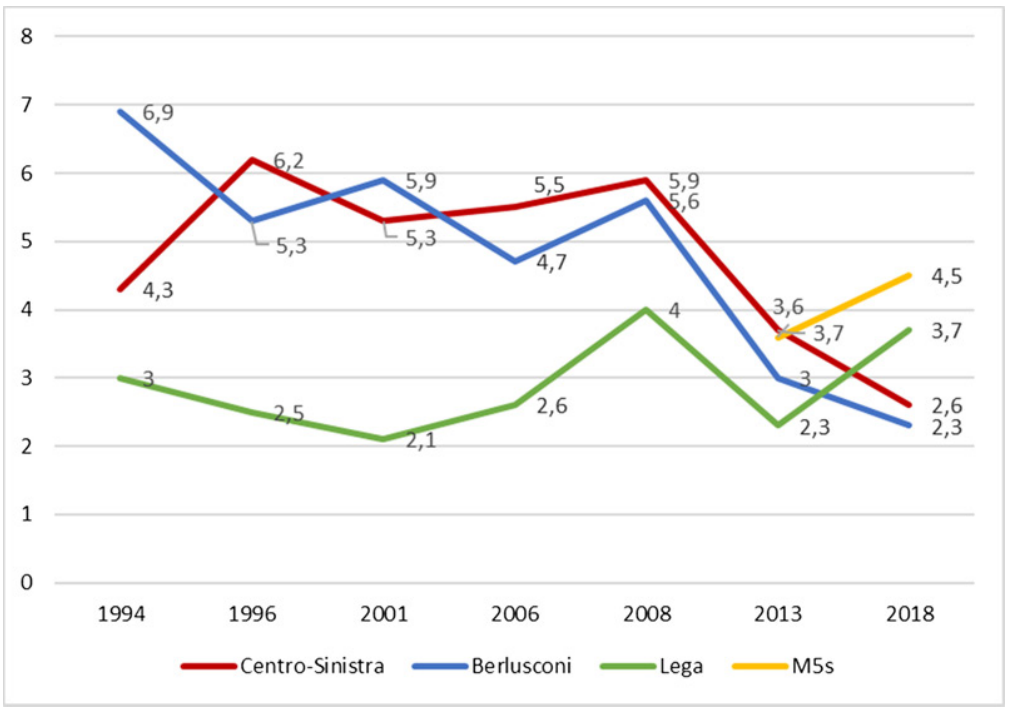

Figure 3. The popularity of main party/coalition leaders in the Second Italian Republic (mean thermometer evaluations). Source: Italian National Election Studies, 1994-2018.

Figure 3 presents the mean thermometer evaluation for the main party/coalition leaders throughout the ITANES series spanning all the elections held in the so-called Second Italian Republic. A number of interesting findings emerge in longitudinal perspective. First, the leaders of the traditional parties (PD and FI) have never been so unpopular. Second, the leader of LN has never been more popular than his traditional coalition partner Silvio Berlusconi. Third, a totally unexperienced leader of a nonparty is now the most popular leader in the country - and yet he is not even remotely as popular as party leaders used to be for a large part of the Second Republic. In other words, if leaders have mattered, they must have done so as a function of something more complex than their mere popularity (or lack of thereof) among the Italian electorate.

A more encompassing explanation should probably depart from the connection between leaders' credibility and the issues more salient to different types of electorate against a background of unprecedentedly widespread anti-party sentiments (Barisione et al. 2018). Indeed, what it seems to have been at work is a blend of issues and perceived competence, with Di Maio largely appreciated by those voters most concerned with unemployment and corruption, and Salvini ranking highest amongst voters concerned primarily with immigration and security. And while both Berlusconi and Renzi scored just too low to be able to attract any specific issue publics, it must be highlighted that Gentiloni managed to be perceived as the best leader by those voters mostly concerned with economic 
Table 3. Leaders' mean thermometer score by most important issues facing the country.

\begin{tabular}{lcccccc}
\hline Most important issue(s) & $N$ & Berlusconi $^{\mathrm{a}}$ & Di Maio $^{\mathrm{a}}$ & Gentiloni $^{\mathrm{b}}$ & Renzi $^{\mathrm{a}}$ & Salvini $^{\mathrm{a}}$ \\
\hline Unemployment & 763 & 2.1 & 4.7 & 4.1 & 2.5 & 3.5 \\
Political corruption & 374 & 1.3 & 4.9 & 3.8 & 2.2 & 2.7 \\
Taxation & 278 & 3.1 & 5.0 & 3.7 & 2.6 & 4.6 \\
Immigration & 268 & 3.3 & 4.4 & 2.9 & 1.9 & 5.9 \\
Economic growth & 235 & 2.4 & 3.9 & 5.0 & 3.1 & 3.4 \\
Fiscal evasion & 158 & 1.5 & 4.1 & 5.7 & 3.2 & 2.5 \\
Public debt & 147 & 2.3 & 4.2 & 5.6 & 3.2 & 3.3 \\
Criminality & 144 & 3.0 & 3.9 & 3.9 & 2.5 & 4.6 \\
\hline
\end{tabular}

Source: a: ITANES post-election study 2018; b: ITANES pre-election study 2018 ; Total $N=1558$. Note: Shaded cells represent the highest values in each row.

growth, reduction of the public debt, and fighting tax evasion (see Table 3). While this latter finding could speak against the choice of the centre-left coalition to downplay the results of the incumbent government led by Paolo Gentiloni himself, it should also be noted that the proportion of voters concerned with such topics was already largely secured in the camp of the centre-left.

\section{Government formation}

Based on the election result, both Salvini (as leader of the most voted-for coalition) and Di Maio (as leader of the most voted-for party) stated their intention of receiving from President Mattarella the task of forming a new government. Eventually, Salvini offered a coalition agreement to the M5S but only on the condition that Berlusconi was part of such a coalition. In spite of Di Maio's rejection of this offer, both M5S and the centre-right took the first steps towards an alliance by agreeing on the names of Roberto Fico (M5S) and Elisabetta Alberti Casellati (FI) as presidents of the two chambers. In April, both Fico and Alberti Casellati were conferred an exploratory mandate to test the possibility of different coalition governments (M5S + PD and M5S + centre-right, respectively). After both attempts failed, President Mattarella announced on 7 May his intention to appoint a 'neutral government'. This occurrence led M5S and LN to request extra time from Mattarella in order to form a government between the two parties. An agreement on the government programme was eventually reached on 13 May, and a week later the two parties proposed the name of Giuseppe Conte, a lawyer and university professor with no previous political experience, as Prime Minister. On 27 May, Conte resigned his office due to a conflict between Salvini and Mattarella on the name of Paolo Savona as Minister of the Economy. As a result, Mattarella conferred on Carlo Cottarelli, former International Monetary Fund (IMF) director, the task of forming a new government. Eventually, his attempt did not 
even make it to the vote of confidence, due to lack of support in parliament. Meanwhile, Matteo Salvini and Luigi Di Maio announced their willingness to restart the negotiations to form a political government. The government was eventually formed on 1 June, under the leadership of Giuseppe Conte and with both $\mathrm{Di}$ Maio and Salvini as deputy prime ministers.

The result of almost three months of negotiation is the so-called Governo del Cambiamento ('government of change'). The circumstances under which this coalition agreement was formed departed massively from the pre-electoral expectation that the M5S would never agree to enter into a coalition and the corresponding assumption that the new government would look like another grand coalition, German-style (Faas 2015). While part of the reason can be attributed to the poor electoral performance of $\mathrm{PD}$, it must also be noted that this falls within a more general trend for established social-democratic parties across Western Europe (van Holsteyn 2018). Similarly, only part of the explanation lies in the unprecedented success of a right-wing populist force like LN, considering that similar parties recently made it to government in countries like Austria (Bodlos and Plescia 2018) and Norway (Aardal and Bergh 2018). If one is to look for the Italian peculiarity in the story, this is likely to be found in the ambiguous part played by the M5S. Di Maio's unexpected decision to enter a coalition government paved the way for Salvini, for the first time in the Lega's history, to enter government without Berlusconi. How long this unprecedented alliance will last remains to be seen. As of now, one can only speculate about the prospects of what looks to many like the first full-fledged populist government in Western Europe. With the European elections of 2019 quickly approaching, Italy's never-ending election campaign is far from being over.

\section{Disclosure statement}

No potential conflict of interest was reported by the author.

\section{Note on contributor}

Diego Garzia is Senior Researcher and Lecturer at the University of Lucerne, and also a returning Visiting Fellow at the Robert Schuman Centre for Advanced Studies in Fiesole. His research investigates the extent to which political leaders have come to affect voters' choice as well as the role played by old and new media in driving this development across time. He currently serves as founding convenor of the ECPR Research Network on Voting Advice Applications (VAAs) and as a member of the Scientific Committee of the Italian National Election Study (ITANES). [diego.garzia@unilu.ch] 


\section{References}

Aardal, Bernt, and Johannes Bergh (2018). 'The 2017 Norwegian Election', West European Politics, 41:5, 1208-1216.

Amato, Rosanna, and Roberto Perotti (2018). 'Fact checking: le promesse dei partiti costano tutte troppo.' La Repubblica. Accessed online at https://rep. repubblica.it/pwa/generale/2018/02/17/news/fact_checking_le_promesse_dei_ partiti_costano_tutte_troppo-189118779/

Albertazzi, D., A. Giovannini, and A. Seddone (2018). “No Regionalism Please, we are Leghisti!" The Transformation of the Italian Lega Nord under the Leadership of Matteo Salvini', Regional \& Federal Studies, 28:5, 645-71.

Barisione, Mauro, Paolo Bellucci, and Cristiano Vezzoni (2018). 'Conclusioni', in Mauro Barisione, Paolo Bellucci \& Cristiano Vezzoni (eds.), Vox Populi. Il voto ad alta voce del 2018. Bologna: Il Mulino, in press.

Barisione, Mauro, Patrizia Catellani, and Diego Garzia (2013). 'Alla ricerca di un leader', in Paolo Bellucci and Paolo Segatti (eds.), Voto Amaro. Disincanto e crisi economica nelle elezioni del 2013. Bologna: Il Mulino, 147-57.

Bodlos, Anita, and Carolina Plescia (2018). 'The 2017 Austrian Snap Election: A Shift Rightward', West European Politics, 41:6, 1354-63.

Ceccarini, Luigi, and Fabio Bordignon (2017). 'Referendum on Renzi: The 2016 Vote on the Italian Constitutional Revision', South European Society and Politics, 22:3, 281-302.

Faas, Torsten (2015). 'The German Federal Election of 2013: Merkel's Triumph, the Disappearance of the Liberal Party, and Yet Another Grand Coalition', West European Politics, 38:1, 238-47.

Garzia, Diego (2013). 'The 2013 Italian Parliamentary Election: Changing Things so Everything Stays the Same.' West European Politics, 36:5, 1095-105.

Garzia, Diego, and Fulvio Venturino (2018). 'I leader di partito nelle elezioni 2018', in Mauro Barisione, Paolo Bellucci, and Cristiano Vezzoni (eds.), Vox Populi. Il voto ad alta voce del 2018. Bologna: Il Mulino, in press.

Mancini, Paolo, and Franca Roncarolo (2018). 'Tanto tuonò che piovve: la campagna elettorale nei giornali e in television', in Mauro Barisione, Paolo Bellucci, and Cristiano Vezzoni (eds.), Vox Populi. Il voto ad alta voce del 2018. Bologna: Il Mulino, in press.

Segatti, Paolo, Monica Poletti, and Cristiano Vezzoni (2015). 'Renzi's Honeymoon Effect: The 2014 European Election in Italy.' South European Society and Politics, 20:3, 311-31.

van Holsteyn, Joop J. M. (2018). 'The Dutch Parliamentary Elections of March 2017.' West European Politics, 41:6, 1364-77. 